\title{
LOCAL AND UNOFFICIAL ARRANGEMENTS FOR LABOR DISPUTE SETTLEMENT
}

\author{
Arthur W. Hepner*
}

In a recent interview an assemblyman from the Jersey City stronghold of Mayor Frank Hague said that the natural inclination of the American working man is to rebel and assert his independence when government tries to force sledge-hammer legislation on his back. His comment alluded to a New Jersey law ${ }^{1}$ which confers on the Governor seizure powers to prevent strikes and lockouts in public utilities. It had, however, a broader application; he was expressing opposition to compulsory methods of any kind for settling labor disputes. Equally under the fire of his remarks were forced arbitration, deprivations of the right to strike, government wage-fixing at state or national levels, and other mandatory programs in which labor has no alternative other than to accept the dictation of an outside agency.

As an alternative to what he considered the sledge-hammer approach, the New Jersey legislator urged the development of voluntary forums. These forums might take various shapes. They might be labor-management conferences, community labor-management-public plans, or mediation services of a wholly advisory character. The important element is that they would give counsel rather than make final and binding adjudications without the specific consents of the parties in dispute.

Without realizing it, the gentleman from New Jersey skirted the new grass that has been growing up in many communities during the past few years. Dozens of the country's larger cities, aware of the need for industrial peace, have been groping, plodding and working to reduce the size of the dangerous area of disagreement which leads to work stoppages, strikes and lockouts. Their formulas differ; their goal is the same. Of the methods developed thus far, three are prototypes on which the others are variations. The basic plans are those of Toledo, Boston and San Francisco.

San Francisco's is an employer plan, unilateral, but the unions appear to like it. The Boston plan embraces labor and management; it is a bi-partite operation bearing no relation to the metropolitan government. Of the three, the Toledo plan alone brings in local government. The Toledo plan is perhaps the best known because its sponsors have seen to it that its story has received wide circulation. In fact, the work-horse of the plan, Jerome Gross, is a former newspaperman and has lent a hand in spreading the gospel through the various pipes of information.

- S.B. 1938, Nieman Fellow, 1945-46, Harvard University. Member of the staff of the St. Lotis PostDispatch. Contributor to The New Republic, Harper's Magaxine, Business Week, and other periodicals in Canada and England. At work on a history of the schism in the American labor movement for publication next year.

${ }^{2}$ N. J. S. A. (Supp., 1946) $34: 13$ B-1 to $34: 13$ B-17. 
The conception of the Toledo plan took place in the spring of 1945 . Resolution R 7I-45 of the Toledo City Council, adopted on April 23, authorized Mayor Lloyd E. Roulet "to appoint a committee of eighteen, consisting of six representatives of management, six representatives of labor and six representatives of the public; for the purpose of studying community management-labor problems." The resolution asserted that full employment was the most important postwar problem facing the city; moreover, that full employment depended on narrowing the areas of disagreement between labor and management "through exploration by labor and management with the aid of the public of ways and means to effect a better understanding and solution of the problems affecting labor and management within the community." Unless the understanding' was reached, the resolution warned, "we are faced with industrial strife and the consequent dislocations and economic losses to the community."

Ten months later the plan was born. ${ }^{2}$ The survey undertaken in accordance with the 1945 resolution produced after a period of gestation what was called a "charter for industrial peace." In the week of Lincoln's birthday, labor and industry in Toledo presumably were emancipated from the bonds of industrial strife; the City Council unanimously approved the charter. Broadly speaking, the Toledo charter provided for a permanent committee of eighteen, embellished by an executive secretary and a full-time director of mediation, fact-finding, and arbitration.

The charter consists of six principles and twice that number of articles. Its brief preamble states: "Industrial harmony is necessary to the welfare of Toledo. Industrial harmony means more than the elimination of strikes, slow-downs and lockouts. It means a practical, common-sense recognition of the rights of both employers and employees, the mutuality of their interests, and the importance of their joint responsibility to the citizens as a whole, whose interests transcend the presumed rights of any group." The six principles declare that management recognizes employees' rights to join unions and bargain collectively; labor recognizes management's right to manage; neither labor nor management shall discriminate against any employee because of race, color or creed. Both agree that increased efficiency and technological advance mean lower costs and prices, wider markets and the likelihood of higher wages, a rising standard of living and increasing employment; both realize that differences and disagreements will arise, but agree that their damaging effects should be minimized by joint discussion and voluntary solicitation of mediation, fact-finding, and arbitration facilities to be made available by the Labor-Management-Citizens' Committee; and both agree that an educational program should be encouraged to promote better understanding among workers, stewards, union offcials, supervisors, foremen, and managers. The twelve articles lay down the modus operandi for the committee. Repeatedly the assertion is made that participation in the plan is entirely voluntary.

N. Y. Times, Feb. 17, 1946, p. 2, col. 2. 
Toledo's plan was prompted by a long history of bitter industrial conflict which from time to time had been pock-marked by violence. In .Igrg National Guardsmen fired on strikers at the Willys-Overland Company; in 1934, two were killed as the result of a strike at the Electric Auto-Lite Company. A Toledo Peace Board was formed with the participation of the American Federation of Labor, and some semblance of order was obtained. But with the establishment of the National War Labor Board early in $1942,{ }^{3}$ the need for the Toledo agency was dissipated and it was abandoned. However, Department of Labor statistics for 1944 indicated that 184,000 man-days had been lost in the city in that year because of work stoppages. ${ }^{4}$ It became apparent to officials in Toledo that precautions were necessary to prevent labor and management from going back to the days of open industrial warfare after the war had ended. So city officials, headed by Vice-Mayor Michael V. DiSalle, advocated formation of the tri-partite committee as a part of the city government.

In its first annual report, covering the last six and a half months of 1946 , the Toledo committee enumerated forty-three disputes which it had handled and said there had been no strikes since October 17 . Between June 15, when the committee set up shop, and October 17 there had been sixteen strikes. In nine it worked out the settlement; the remaining seven were settled without its intervention. Percentagewise, the record is fair. Although nearly $4^{\circ}$ per cent of the disputes which came to its attention reached the strike stage, it settled nearly 60 per cent of them. The committee claims to have averted twenty strikes and adds that in ten other cases the disputes were compromised after it had arranged meetings between union and management and recommended further negotiation. On one occasion, in a dispute involving the AFL Teamsters' Union, public members of the committec acted as arbitrators and rendered a final and binding decision.

Tests of the effectiveness of the Toledo concept became possible even before the committee was set up as a part of the municipal government. As the original survey was being made, CIO warehouse workers went on strike. They had been out nearly six weeks when the committee of eighteen decided to move in. The public members called in the union and employer representatives separately and apprised them of the damage the strike was causing to the community's welfare. Within seventy-two hours the strike ended. Another dispute in which the committee intervened was in a textile plant. Word reached the group that the union had planned a mass picketing demonstration in the center of the city on a Saturday afternoon. Vice-Mayor DiSalle, speaking for the committee, notified the management of the textile company that the projected demonstration could have serious effects on the city. He counseled the management to take steps to resolve the dispute. Meanwhile, one of the labor members carried the same message to the strikers.

Exec. Order 9017, Jan. 12, 1942.

U. S. Bur. Lab. Stat., Bull. No. 833 (1945), II-12. 
They were back at work the following Monday. There had been no interference with Saturday's commerce and trade.

Another incident, in which the committee indirectly aided in a critical dispute, involved the Libby-Owens-Ford Glass Company. It was said that the "human association" of John D. Biggers, president of the company, with labor members of the committee resulted in the absence of animosity during the dispute. Although a strike was called, there was no picketing; labor committees were given access to the plants to make certain no attempts were being made to operate, and inflammatory rumors were promptly exposed. When the plant re-opened, relations between union and management were unusually good. Mr. Biggers, who is an industry member of the Toledo committee, and union officers sent a remarkable letter to employees at the end of the strike. Among other things it said: "We as officials of the union and the company are all thankful that the glass strike is ended. We will do everything possible in the future to avoid a repetition. ... The company is glad to have you back at work in its factories. The union and each of you are assured of the good will of the company. The union likewise assures the company of its good will and co-operation. Co-operation between men and management will insure good production. Good production is the best possible insurance of good wages. You, the union and the company, are a team in this industry. We lose ground or succeed together."

The Toledo plan employs a useful, if unorthodox, technique, less politely known as the "back-door" method. It drops all pretense of formality and gets "the boys" together to talk over their grievances. The first step is initiated by the executive secretary. Notified of a dispute among participants in the plan, he summons them into an informal conference. If he cannot make headway in his office, over sandwiches and coffee, he recommends mediation, fact-finding, or, as a final step, arbitration. The disputants are not obligated to accept any of these recommendations, but the informal nature of the plan, together with the fact that its findings are made public, inclines labor and management to co-operate. Not all unions and companies in the community have joined the plan, for in many quarters there is some doubt as to its value. Obviously, the committee can work only with affliated unions and managements; it cannot hope to make any impression on groups which deny its validity.

The theory behind the Toledo plan is that through regular meetings of the committee labor and industry members will get to know each other and develop a mutual understanding of each other's problems. On the basis of the confidence developed, it is assumed, they will be able to work out with the public members methods for maintaining a high level of industrial peace. Through tri-partite collaboration it is expected they will reach conclusions and recommend policies designed to promote the welfare of the community.

Other cities have inquired about the plan. The first report, in addition to citing 
statistics of results, recalls that requests for information have been received from 225 city and state officials. Among the cities which have considered introducing their own versions of the Toledo plan have been St. Louis, Denver, New Orleans, Milwaukee, Tulsa, Kansas City, Detroit, and two Canadian cities, Montreal and Windsor, Ontario. Moreover, the United States Conference of Mayors requested that data regarding the plan be sent to $55^{\circ}$ city administrations.

Louisville, Kentucky, inaugurated a plan modeled after Toledo's in July, 2946. Its committee is composed also of eighteen members, giving equal representation to labor, management and the public. The day following the inception of the plan city garbage collectors belonging to a $\mathrm{CIO}$ union struck for higher wages, adjustment of grievances, and union recognition. Although city officials conceded the justice of the wage demand, city coffers lacked funds to meet it. The new committee, attacking the problem, ascertained that a reshuffling of the Sanitation Department's budget would permit an increase of $12^{1 / 2}$ cents an hour. Five days later the men were back at work assured of union recognition, in return for which they pledged to refer future disputes to the committee for settlement. The Louisville committee met other challenges with equal acuteness and avoided, among other threats, a proposed general strike by the AFL over the city's denial to policemen of the right to organize.

Unlike Toledo's, the Louisville committee is not an adjunct of the municipal government. It is a completely independent body. One criticism lodged against it is that its public members should, according to the logistics of the class struggle, incline toward a management viewpoint. The public membership includes Mark D. Ethridge, publisher of the Louisville Courier-Journal, and Charles W. Williams, head of the economics department of the University of Louisville. Both, as well as other public members of the committee, are men of broad, liberal vision. Labor and management have found their counsel impartial and the unions as well as management have heartily endorsed the Louisville plan.

Of the cities which have investigated the Toledo formula, only in St. Louis have the unions turned a cold shoulder toward it. Here both CIO and AFL central bodies have denounced the plan and refused to participate in it, even to the extent of prohibiting members from engaging in preliminary discussions. In the case of the AFL, the rejection resulted from internal politics. The central trades and labor union originally voted to designate representatives to attend the exploratory talks. But a week later, business agents of the AFL unions cancelled out the rank-and-file mandate by voting to abstain from any conference on the subject.

The CIO was more unified. CIO held that the United States Conciliation Service and the National Labor Relations Board adequately answered the needs of labor and management. Rather than the creation of another agency, it advocated a strengthening of Conciliation Service and NLRB facilities. On the basis of its previous experience during the war with a labor-management committec under Mayor 
Kaufmann, the CIO had little faith in a community plan. It contended that the Mayor co-operated superbly when trying to increase output for management or induce new industries to enter the city, but charged him with shutting the door in CIO's face when it demanded the committee's aid in obtaining severance pay for discharged war workers, union recognition, settlement of grievances, or other goals sought by organized labor. CIO's attitude was epitomized by a declaration that labor had better beware the attempt to stampede it into peace plans which must ultimately lead to compulsory arbitration. Whatever the merits of this position, the refusal of CIO and of AFL to co-operate with the Mayor doomed the plan for St. Louis.

In the District of Columbia the Council of Social Agencies recently advocated a Toledo-type plan. Its recommendation called for creation under the District government of a voluntary committee, tri-partite in composition, to reduce the number of strikes and to promote amicable industrial relations. Most of the disputes arising in the District, the council noted, were purely local and required local machinery for settlement. No such machinery had been available. When intervention became necessary in a hotel strike, it was Reconversion Director John R. Steelman who had to mediate and work out the settlement. In contrast to the CIO view in St. Louis, the Washington group considered the United States Conciliation Service inadequate or unsuitable for coping with local disputes. The same day that the council made its recommendations, the Gallup poll reported that $5^{2}$ per cent of persons interviewed on the Toledo idea thought such a plan would work in their own communities. On the negative side 23 per cent thought it was impractical, while the middle 25 per cent had no opinion on the subject.

Shortly after the council's recommendations were made public, the United States . Conciliation Service created a 24-man Labor-Management Assembly for five Middle Atlantic states and the District of Columbia. ${ }^{5}$ This body, composed of ten management representatives, five representatives from each of the two major labor organizations, two corporation lawyers, and two labor lawyers, will act in an advisory or mediatory capacity in disputes of national or state-wide importance. The Assembly will assist the Conciliation Service just as management and labor members of the Toledo committee aid the executive secretary in softening up the disputants for mediation. States in the group are Pennsylvania, Maryland, Deleware, southern New Jersey and Virginia.

The Conciliation Service project, however, bears a closer resemblance to the Boston formula than to the Toledo plan. It is primarily bi-partite in structure, with the public represented only by the member of the Conciliation Service who acts as impartial chairman of the group at its full joint meetings. A clearer glimpse into its future workings may be had by an analysis of the structure and operations of the Industrial Relations Council of Metropolitan Boston.

8 I9 L. R. R. 86-87 (1946). 
Boston, the cradle of this country's first native political institutions, claims the distinction of having developed the first general community program for settlement of labor-management controversies that entirely rules out government participation. Its plan was conceived in 1940, and after a year of preparation was ready for business on the eve of Pearl Harbor. It grew out of a desire of the Industrial Relations Committee of the Boston Chamber of Commerce to enlarge the body by inclusion of labor representation, but the natural suspicion of labor men against a Chamber of Commerce taint led to the formation of an independent agency.

In its final form, the plan provided for an executive committee of fourteen members to run the affairs of the council. Of the members of the Executive Committee, six represent management, three the AFL and three the CIO. The other two are a public member-at present President Daniel L. Marsh of Boston Universityand an executive secretary. Members of the council are business and industrial firms and labor unions which desire to affiliate. The operating expenses are paid out of membership fees which are \$1o annually for local unions and from $\$ 5$ to $\$ 75$ for employers, depending upon the number of persons they employ.

The nub of the program, in the tradition of New England's hallowed town meetings, is talk. The council encourages the talking out of mutual problems at mass conferences, periodic committee meetings, and on a weckly radio program. Subject-matter covers a wide gamut, from individual union practices and collective bargaining to administration of contracts and joint political action on issues of mutual interest. The main attraction annually is a one-day conference of labor and management, addressed by labor, management and public figures of national prominence. Smaller conferences are sponsored during the year by the CIO, AFL and management groups respectively, and are restricted to attendance by members of the sponsoring factions.

These get-togethers are but the trappings. The real operations of the council are carried on through frequent meetings of the executive and subsidiary committees, at which small and intimate groups of labor leaders and businessmen cultivate the practice of unravelling mutual problems harmoniously. There are also the day-today activitiss of the executiue secretary. The executive secretary serves as a general factotum and, when necessary, as dulcifier to dyspeptic union representatives and plant managers. On the telephone or in conference, it is his job to use tact and knowledge of human beings and labor relations "to destroy the mustard seed before it begins to germinate."

He works along these lines, which are somewhat similar to the technique used at Toledo: A union representative complains of unreasonable obstinacy from a given firm. The executive secretary communicates with the head of the firm, directly if he knows him personally or through the help of a mutual friend who usually turns out to be a member of the executive committee. He tries to bring the disputing parties into his office or into a meeting at some other place where the three of them 
"talk things over." The same procedure is followed when management complains against a union, because the policy and method is admittedly to exploit personal relationships. Not always, however, does this "talk-things-over" approach succeed. When it fails, the council provides complete conciliation, mediation and arbitration facilities. These services are supervised by a conciliation subcommittee which is composed equally of labor and management men. It makes available one-man, bipartite, or tri-partite panels on request of the disputing parties. But the entire operation is wholly voluntary; the council has no power but that of persuasion.

By and large, labor and management in the Boston area endorse the program. Notable exceptions are the left-wing elements in the CIO. Although local officers co-operate individually with the council, the left-wing organizations boycott it. This abstention has been attributed to the abhorrence with which Communists and fellow-travelers regard the development of labor-management programs impeding access to the government. The council has been impotent, its members admit, in the face of national strikes or in disputes in which its intervention is resented by either labor or management. It can operate efficiently only as a voluntary body and upon the direct solicitation of the disputants. Even if the executive secretary attempts to set up a meeting between disputants there can be no successful stride made toward compromise unless both labor and management agree to enter the meeting.

One practical view applicable to all voluntary and unofficial dispute-settlement programs has been advanced by the present chairman of the Boston council, Fredcrick W. Bliss, an industry member of the executive committee: "The problem is to get common sense into everyday plant relations. This means labor and management must be taken away from the heat of a plant disturbance to learn that the other fellow is human, too. Labor and management must meet, moreover, at times other than when disputes are in progress; this idea of meeting the other side only when there's a fight has been the cause of too much trouble in the past." It was Bliss who, as head of the Boston Chamber's Industrial Relations Committee, gave the impetus to creation of the Boston plan. The record shows that in the year following V-J Day, arbitration was requested in only four cases, and in these, as well as in the several cases informally conciliated, settlement was reached without a work interruption.

More than 3,000 miles west of Boston, the third basic type of plan was developed in 1939 at San Francisco. It is an Employers' Council, dealing with organized labor from the standpoint of the community's welfare as a whole. San Francisco with its record of brutality in labor relations and its general strikes needed some relief from violent industrial embroilments. An Industrial Council, prior to I939, was generally considered a "union-busting" organization." Its anti-labor sentiments

\footnotetext{
'In 1923 a United States District court held that the Industrial Association of San Francisco, in sekking to enforce the so-called "American plan" in the local building industry, was engaged in a conspiracy in restraint of interstate commerce in violation of the Sherman Act, and issued an injunction at the instance of the Department of Justice. Builders and contractors were required by the association
} 
led Roger Lapham, then a steamship company executive but now Mayor of San Francisco, to propose "that the employers of San Francisco develop some kind of federation with the idea of honestly trying to establish better relations between employer and employee." Out of this recommendation the present council grew. It resembles a trade council in structure.

It has two kinds of members: industry groups and individual employers. Of all industries in the city only the building construction industry, which has its own dispute settlement machinery, has not joined the council. There are about 2,000 members. In addition to a board of directors which formulates policy, the council has a professional staff of thirty-six economists, lawyers, negotiators, and researchers, headed by William G. Storie, executive vice president.

The basis of the council's dealings with organized labor is a master contract. This is believed by the members to be a contract in the best interests of all the employers in a given group and their employees. Both sides must live up to it. If a union takes action against any member of a group of employers in violation of its contract, the council calls for a lockout in all plants belonging to the group. Contrariwise, if an employer violates the contract, he becomes subject to strict disciplinary action. No member of the council is empowered to make any offer to his employees which is not in conformity with industry-wide practice. Should a member desire to make an innovation, he must present it to the council for consideration and a decision of the professional staff which is binding. The penalty for violation by an employer is expulsion 'from the council, and this, in more than one case, has forced employers to sustain heavy loses through boycotting by labor, industry and other groups.

As in Boston and Toledo, the formalities are merely the frosting. The real work is done by way of the "back-door" method. In an informal setting, the question of a wage demand is reduced from "What are you asking?" to "What do you want?" The professional staff knows all the ins and outs of negotiating and there is neither need nor desire for intellectal sparring. The staff member and the union representative can get right to the point. As Storie put it to Ted P. Wagner, a reporter of the St. Louis Post-Dispatch investigating the San Francisco plan, "We get the baloney out in a hurry, and get down to facts." When contracts are under discussion two union men and two council agents negotiate. If they cannot reach a decision, the members of this group select an impartial arbitrator whose decision is binding.

Regardless of conflicting opinions of the council, ${ }^{7}$ its record is noteworthy. Be-

to obtain a "permit" to purchase certain materials; the permit could be obtaincd only if the contractor pledged that he would conduct his business according to the plan. U. S. v. Industrial Ass'n of San Francisco, 293 FED. 925 (N. D. Cal. 1923), rev'd 268 U. S. 64 (1924) on the ground that the cffect on interstate commerce had not been sufficiently established. [Ed.]

${ }^{7}$ Caution and a thorough investigation of the details of the plan would appear to be in order before it is imitated by other groups. The case of U. S. v. Industrial Ass'n of San Francisco, 293 FED. 925 (N. D. Cal. 1923), cited supra note 6, suggests the danger that concerted action by employers to enforce 
tween 1939 and 1944 strikes throughout the nation increased 52 per cent. But in San Francisco during the same period they declined 80 per cent. There were only eight strikes in 1943 , involving 3,377 workers. In I944 there were a dozen strikes, but they involved only 1,316 employees. Nevertheless, the council has encountered some difficult situations. Storie admits it took an "awful licking" in I94I when seventy-seven restaurants were shut down for seven weeks by a culinary workers' walkout. Storie does not contend that the council can doctor all labor's ills. In his opinion, it happens to be tailor-made for San Francisco, but there are many other places in which it would not succeed.

Apart from the municipal programs, several states have taken various steps to cope with industrial difficulties. New York, ${ }^{8}$ New Jersey ${ }^{9}$ and other states have developed their own mediation agencies, supplementing the services of Federal agencies. Illinois ${ }^{10}$ and other states have conciliation services. Many governors in messages to their legislatures have taken cognizance of the need for voluntary state programs.

The New Jersey State Board of Mediation may be taken as typical. This agency was created in I94I. It is an adjunct of the state Department of Labor and, except in disputes involving public utilities, provides a voluntary service. The board consists of seven men, two representing labor, two representing management, and three representing the public. Board members render services on a per-diem basis, but the budget provides for a full-time staff of four mediators and several clerical employees. The law creating the agency authorizes it to endeavor to prevent threatened work stoppages and to try to settle disputes which cannot be resolvied by the parties themselves. When a dispute arises the board may intervene through its representatives on its own motion or upon request of either of the disputing parties. The nature of its intervention is left to the discretion of the staff. There are many alternatives: board representatives may stage "back-door" conferences, or they may try to bring the disputants together into a formal meeting at the board's offices. In effect, the board's representatives use the tactics of conciliators or mediators, and, in an impasse, may recommend arbitration. In that event, the board supervises selection of the arbitration panel, which must be constituted on a tri-partite basis. The board can only make recommendations; it cannot compel the parties to accept them. But like the various municipal agencies, it has the weight of public opinion solidly behind it.

Early in 1946 , the New Jersey legislature strengthened the hand of the board for

adherence to a common labor policy through the use of boycotts may violate anti-trust laws. In addition, such plans may involve violation of $\$ 8(5)$ of the National Labor Relations Act if the terms of the agreement prohibit bargaining by employers concerning matters within the statutory obligation to bargain collectively. The question is presented in a case now pending before the National Labor Relations Board, involving the Hawaiian Employers' Council, which is said to have been patterned after the San Francisco plan. Matter of Shell Oil Co., 23-C-40. See also Collective Bargaining With Associations and Groups of Employers, 64 Mo. LnB. REv. 397 (1947). [Ed.]

N. Y. LABor LAW \$\$750-758.

-N. J. S. A. (Supp., 1946) 34:13A-1 to 34:13A-13.

${ }^{20}$ IzL. Stat. AN. (Jones, Supp. 1946) \$109.020-109.030. 
coping with disputes in public utilities. ${ }^{11}$ It required public utilities and their unions by law to negotiate before an "open window" with the board looking through. Specifically, utilities and their unions must notify the board of intentions to negotiate or renegotiate contracts, simultaneously with notifying the other party. If the unions and the utilities are unable to come to agreement or are unwilling to submit the unsettled issues to arbitration by the time the contract expires, the mediation board moves in. It sets up fact-finding panels of a tri-partite character and directs them to schedule public hearings. The findings of the panel together with recommendations are reported to the Governor, who, if a strike or lockout is likely, may seize and operate the utility. In all this there is a voluntary element; at present the board and the Governor are powerless to compel union or utility to accept the findings or to penalize workers who strike following seizure by the state. They rely solely on powers of persuasion buttressed by public opinion. There is on foot, however, a movement in New Jersey to add penalties to this public utilities bargaining law.

In his message to the Eightieth Congress, President Truman urged creation of a labor-management conference to assess the need for new labor legislation on a national scale. While the recommendations of the conference presumably would be enacted into law, they would have an element of voluntarism in them to the extent that they might be espoused by representatives of labor and management. Some states, including New Jersey, are contemplating the convocation of similar conferences. And at the recent United States Conference of Mayors held in Washington, Mayor Hubert $\mathrm{H}$. Humphrey of Minneapolis expressed the belief that since committees had worked for him on everything else-taxes, health, housing, and traffic-they should be able also to help in the settlement of labor problems. He was confident that solutions could always be found by getting people to "sit on the inside." .

The establishment of home-grown voluntary dispute-settlement plans has the endorsement of Reconversion Director Steelman. He believes they would accomplish what Government agencies at the national capital have been trying to achieve for some time. "to keep the country from asking Washington to settle local industrial problems." These plans, Steelman thinks, put the responsibility for industrial peace where it properly belongs-on the local community. Rather than impede, they augment the United States Conciliation Service, which is always available if the local agency fails. Mr. Steelman thinks he can claim credit for a part of the idea underlying the Toledo plan. When he was chief of the Conciliation Service, he instituted the practice of assigning permanent conciliators to various cities throughout the country. Before that, conciliators moved in from Washington as individual disputes arose. By assigning conciliators to live in a given community and become active members of that community, Steelman enabled them to learn

${ }^{21}$ N. J. S. A. (Supp., 1946) 34:13B-r in $34: 13 B-17$. 
about local conditions and make friends among labor union and management officials. This friendship, he has said, paved the way to quicker settlements when the conciliators were called on to intercede in disputes.

An important factor supporting these voluntary plans is public opinion. In most cases officials work closely with the press, and they can "blackjack" a union or a company into acting in the interests of the community as a whole by threatening to give all the gory details of the dispute to the press. At the plan's command, also, generally are religious and civic agencies which can be enlisted to make the disputants come to reason. There is a host of other pressures accessible, if needed. Admittedly, these voluntary and unofficial plans sometimes resort to extremes to protect the public interest. This poses a problem in ethics. Should the operating body think first of the private rights of the small group? Or should it endeavor to suppress that private right in the interests of the larger community? If its action is predicated on a philosophy of the greatest good for the greatest number, then it may justifiably take extreme steps against recalcitrant unions or employers. It will not be guilty of violating the trust placed in it. Nor will it be guilty of overstepping the boundaries of voluntary action. Instead, it will be acting in the longrange interests of the community and of the union or management involved because, by promoting industrial peace in this way, it will obviate the need for "sledgehammer" legislation enacted by a Congress inclined to be hostile toward organized labor. Labor and management, with official or unofficial aid from the local communities, will have to develop voluntary dispute-settlement programs that will work, or endure the mercy of Congressional legislation. 